Check for updates

Cite this: Phys. Chem. Chem. Phys., 2020, 22, 12028

Received 16th January 2020, Accepted 22nd April 2020

DOI: $10.1039 / \mathrm{d} 0 \mathrm{cp} 00272 \mathrm{k}$

rsc.li/pccp

\title{
Evidence for lactone formation during infrared multiple photon dissociation spectroscopy of bromoalkanoate doped salt clusters $\dagger$
}

\author{
Nina K. Bersenkowitsch, Milan Ončák, (D) * Jakob Heller, Tobias F. Pascher, \\ Christian van der Linde (D) and Martin K. Beyer (D)*
}

\begin{abstract}
Reaction mechanisms of organic molecules in a salt environment are of fundamental interest and are potentially relevant for atmospheric chemistry, in particular sea-salt aerosols. Here, we found evidence for lactone formation upon infrared multiple photon dissociation (IRMPD) of non-covalent bromoalkanoate complexes as well as bromoalkanoate embedded in sodium iodide clusters. The mechanism of lactone formation from bromoalkanoates of different chain lengths is studied in the gas phase with and without salt environment by a combination of IRMPD and quantum chemical calculations. IRMPD spectra are recorded in the $833-3846 \mathrm{~cm}^{-1}$ range by irradiating the clusters with tunable laser systems while they are stored in the cell of a Fourier transform ion cyclotron resonance (FT-ICR) mass spectrometer. The measurements of the binary complex $\mathrm{Br}\left(\mathrm{CH}_{2}\right)_{m} \mathrm{COOH} \cdot \mathrm{Br}\left(\mathrm{CH}_{2}\right)_{m} \mathrm{COO}^{-}$for $m=4$ indicate valerolactone formation without salt environment while lactone formation is hindered for longer chain lengths. When embedded in sodium iodide clusters, butyrolactone formation from 4-bromobutyrate seems to take place already during formation of the doped clusters in the electrospray process, evidenced by the infrared (IR) signature of the lactone. In contrast, IRMPD spectra of sodium iodide clusters containing 5-bromovalerate contain signatures for both valerate as well as valerolactone. In both cases, however, a neutral fragment corresponding to the mass of valerolactone is eliminated, indicating that ring formation can be activated by IR light in the salt cluster. Quantum chemical calculations show that already complexation with one sodium ion significantly increases the barrier for lactone formation for all chain lengths. IRMPD of sodium iodide clusters doped with neutral bromoalkanoic acid molecules proceeds by elimination of $\mathrm{HI}$ or desorption of the intact acid molecule from the cluster.
\end{abstract}

\section{Introduction}

When it comes to modelling the climate, the investigation of aerosols plays an important role. ${ }^{1-5}$ Tropospheric aerosols contribute to processes such as cloud formation. ${ }^{6}$ As the ocean covers more than $70 \%$ of the Earths' surface, marine aerosols ${ }^{7}$ constitute a significant fraction of the tropospheric aerosol inventory. They are produced via the mechanical disruption of the sea surface. ${ }^{8}$ Marine aerosols are composed of a complex mixture of species that include not only salt, but also a large amount of organic matter. ${ }^{9-12}$ The exposure to intense solar radiation induces complex photoprocessing of organic matter in sea-salt aerosols. ${ }^{13,14}$ It is known that carbonaceous particles

Institut für Ionenphysik und Angewandte Physik, Universität Innsbruck, Technikerstraße 25, 6020 Innsbruck, Austria. E-mail: milan.oncak@uibk.ac.at, martin.beyer@uibk.ac.at

$\dagger$ Electronic supplementary information (ESI) available. See DOI: 10.1039/ d0cp00272k with acidic character appear with a quite high concentration in marine aerosols. ${ }^{15,16}$ Volatile organic compounds ${ }^{17}$ (VOCs) from anthropogenic and biogenic sources undergo rapid transformation via photolysis. ${ }^{18}$

Halogens are very reactive species, and brominated alkanes are reported to be a source of bromine in the stratosphere ${ }^{19}$ where bromine participates in the catalytic destruction of ozone. ${ }^{20}$ Several studies reported the presence of $n$-alkanes and $n$-alkanoic acids in aerosols. ${ }^{21-24}$ Ground water pollution ${ }^{25-29}$ is a highly relevant topic as it affects directly human health ${ }^{27,30,31}$ and environment. ${ }^{32}$ Inorganic $^{33,34}$ and organic ${ }^{35-38}$ pollutants as some (di-)bromoalkanoic pesticides ${ }^{39-41}$ and volatile halogenated bromoalkanes $^{42}$ have already been identified. 3-Bromopyruvic acid is a potential anti-cancer drug and, if applied to patients, will make its way via wastewater to the oceans. ${ }^{43}$ Vogel et al. ${ }^{44}$ studied the reactivity of some mono- and di-bromoalkanes in aqueous buffers. A large variety of halogenated organic molecules are formed as disinfection byproducts in the reaction of disinfectants with natural organic matter and bromide or iodide. ${ }^{45}$ 
These pollutants can easily get into the ocean, and can be therefore present in sea salt aerosols.

Visible or near-infrared one photon vibrational overtone excitation has the potential to trigger atmospheric reactions. ${ }^{46}$ In laboratory experiments, however, infrared multiple photon dissociation (IRMPD) is usually performed at longer wavelengths to obtain action spectra of clusters and ions. ${ }^{4-50}$ It is well established that resonant infrared irradiation may activate chemical reactions in clusters, used e.g. to characterize ionmolecule reaction products. ${ }^{51,52}$ A detailed IRMPD study of $\mathrm{N}_{2} \mathrm{O}$ decomposition on rhodium clusters by Mackenzie and co-workers revealed the influence of co-adsorbed oxygen. ${ }^{53}$ However, even black-body infrared radiation is able to trigger $\mathrm{N}_{2} \mathrm{O}$ decomposition on small rhodium clusters, showing that no mode-specificity is involved. ${ }^{54}$ We have recently investigated the IR induced decomposition of copper formate,,$^{55,56}$ and measured IRMPD spectra of $\mathrm{CO}_{2}{ }^{\bullet-}\left(\mathrm{H}_{2} \mathrm{O}\right)_{n}$ and $\mathrm{Co}\left(\mathrm{CO}_{2}\right)\left(\mathrm{H}_{2} \mathrm{O}\right)_{n}{ }^{-57,58}$ of particular interest to the present work, however, are our recent studies on salt clusters doped with organic molecules, where we used IRMPD to elucidate structural properties ${ }^{59,60}$ and UV excitation to analyze the influence of the salt environment on glyoxylate photochemistry. ${ }^{61}$

To get a better understanding of the chemistry of brominated organic molecules in a salt environment, we performed IRMPD on anionic complexes of $n$-bromoalkanoic acid $(n=5,8)$ and the corresponding $n$-bromoalkanoate, i.e. $\mathrm{Br}\left(\mathrm{CH}_{2}\right)_{n-1} \mathrm{COOH}$. $\mathrm{Br}\left(\mathrm{CH}_{2}\right)_{n-1} \mathrm{COO}^{-}$. We then repeated the experiments with sodium iodide clusters in which one $\mathrm{I}^{-}$ion was replaced by a bromoalkanoate ion, $\mathrm{Na}_{6} \mathrm{I}_{4} \mathrm{Br}\left(\mathrm{CH}_{2}\right)_{n-1} \mathrm{COO}^{+}$, as well as sodium iodide cluster with one molecule of bromoalkanoic acid adsorbed, $\mathrm{Na}_{6} \mathrm{I}_{5} \mathrm{Br}\left(\mathrm{CH}_{2}\right)_{n-1} \mathrm{COOH}^{+}$. Elimination of neutral $\left(\mathrm{CH}_{2}\right)_{n-1} \mathrm{OCO}$, which indicates lactone formation, is exclusively observed for bromoalkanoate species. Complexation with salt reduces the propensity for $\left(\mathrm{CH}_{2}\right)_{n-1} \mathrm{OCO}$ elimination. Quantum chemical calculations provide a molecular level understanding of the observed IRMPD pathways.

\section{Experimental and computational details}

The detailed setup of the experiment was already described elsewhere. ${ }^{62}$ Briefly, the main setup consists of a Bruker APEX Qe 9.4 T Fourier-Transform Ion Cyclotron Resonance (FT-ICR) Mass Spectrometer, equipped with an ESI/MALDI Dual Source II and a Nanobay Console. Doped sodium iodide clusters are generated by electrospray ionization (ESI) of a $5 \mathrm{mM} \mathrm{NaI}$ solution in a 1:1 mixture of $\mathrm{MeOH}: \mathrm{H}_{2} \mathrm{O}$, containing the respective bromoalkanoic acid at a concentration of 1-5 mM. All chemicals were purchased from Sigma-Aldrich, with a purity of at least $98 \%$. Mass selected cluster ions are irradiated with light from two tunable laser systems, emitting IR light at 3846$2234 \mathrm{~cm}^{-1}$ (EKSPLA NT277, $1000 \mathrm{~Hz}$ repetition rate, typical power 25-100 $\mathrm{mW}$ ) and at 2234-833 $\mathrm{cm}^{-1}$ (EKSPLA NT273-XIR, $1000 \mathrm{~Hz}$ repetition rate, typical power $2-30 \mathrm{~mW}$ ). A plot of the laser power as a function of wavelength is available as ESI, $\dagger$ Fig. S1.
IR absorption cross sections are derived by assuming sequential photon absorption following first-order kinetics, as described in detail before, ${ }^{59}$ not considering radiative cooling. The contribution of ambient black-body infrared radiative dissociation $(B I R D)^{63}$ was taken into account as much as possible. For single photon cross sections, the rate of unimolecular decomposition due to BIRD $^{59}$ was measured by storing the ions for different time intervals without laser irradiation. For multiphoton cross sections, the fragment intensity due to BIRD was subtracted before further analysis. IRMPD spectra are recorded by scanning the laser frequency and monitoring the intensity of the dissociation products by mass spectrometry. The influence of the laser pulse energy is corrected within the calculation of the displayed cross sections and IRMPD yield. Overview spectra were obtained in the region where absorptions could be expected by scanning the laser typically in steps of $20-30 \mathrm{~nm}$. The absorption bands identified in this way were re-measured with smaller steps and are shown here. Overview spectra are available in the ESI $\dagger$ (Fig. S2 and S3).

The clusters were investigated using methods of computational chemistry at the B3LYP/def2TZVP level of theory, considering several isomers for each ion. For the bromoalkanoic acid/alkanoate complex, different conformations of the $\mathrm{COOH}$ hydrogen bond were considered, with and without lactone formation. For salt complexes, we employed different $\mathrm{Na}_{6} \mathrm{I}_{5}{ }^{+}$ clusters $^{59}$ and replaced one $\mathrm{I}^{-}$ion by the respective alkanoate. Calculated IR spectra were scaled by a factor of 0.97 and displayed with Gaussian broadening with a full width at half maximum (FWHM) of $30 \mathrm{~cm}^{-1}$. All structures represent local minima on the potential energy surface. Relative energies are reported with zero-point energy correction, but without thermal corrections. All calculations were performed in the Gaussian program. $^{64}$

\section{Results and discussion}

\section{Evidence for lactone formation in $\mathrm{Br}\left(\mathrm{CH}_{2}\right)_{m} \mathrm{COOH}$. $\operatorname{Br}\left(\mathrm{CH}_{2}\right)_{m} \mathrm{COO}^{-}(m=4,7)$}

First, we focus on the anionic complexes $\mathrm{Br}\left(\mathrm{CH}_{2}\right)_{m} \mathrm{COOH}$. $\mathrm{Br}\left(\mathrm{CH}_{2}\right)_{m} \mathrm{COO}^{-}$to identify potential reaction pathways of bromoalkanoic acids and bromoalkanoates in the gas phase, in the absence of a salt environment. Fig. 1a and d shows the IRMPD yield spectra normalized to the most intense absorption, and Fig. 1b and e illustrates the experimental multiphoton cross sections of these species for $m=4,7$. Calculated structures of selected low-lying isomers are shown in Fig. 2 with the corresponding spectra in Fig. 1c and f. Two structure types are considered, with and without pre-formed lactone. For $m=4$, the more stable isomers Ia-c contain lactone while isomers Id-f feature the intact alkanoate $\mathrm{Br}\left(\mathrm{CH}_{2}\right)_{4} \mathrm{COO}^{-}$. For $m=7$, the structures containing lactone, isomers IId-e, lie higher in energy than the alkanoate. Table 1 summarizes the reactions, energetics and branching ratios of the fragments, where the latter were calculated via the integrated experimental curves. The notations IR1, IR2 and IR3 indicate different infrared 
$-\mathrm{Br}^{-}-\mathrm{Br}\left(\mathrm{CH}_{2}\right)_{m} \mathrm{COO}^{-}$ $-\operatorname{Br}\left(\mathrm{CH}_{2}\right)_{m}$
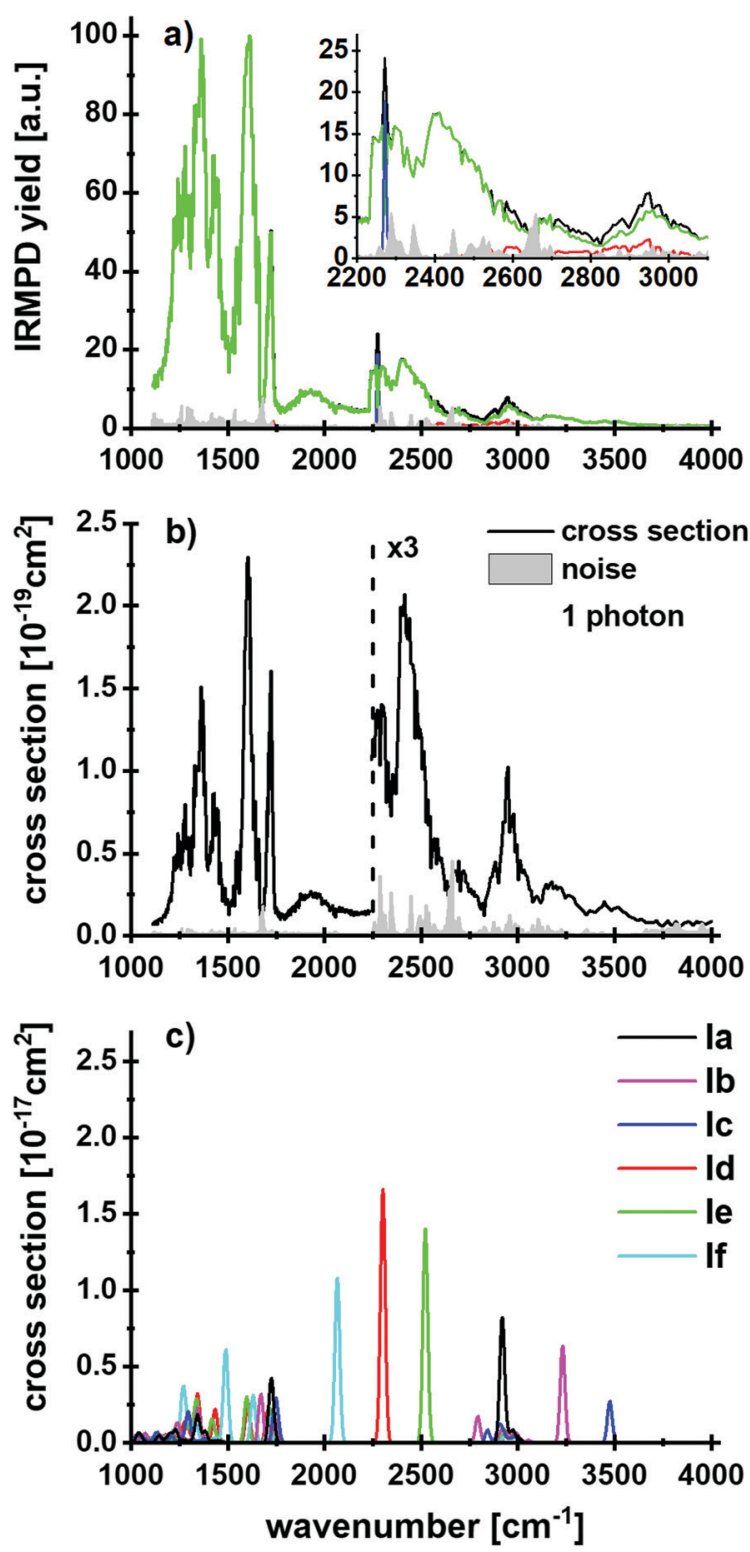
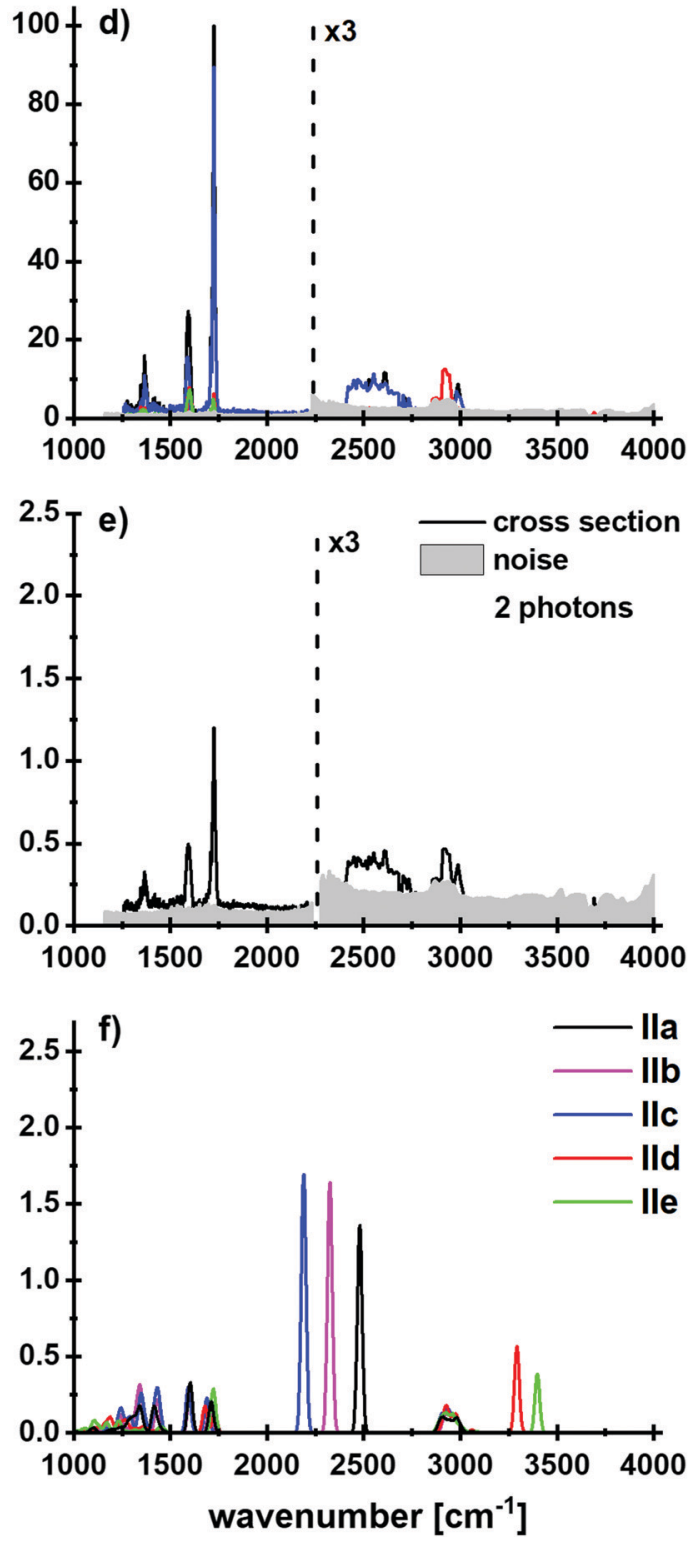

Fig. 1 ( $a$ and d) IRMPD yield spectra with the total yield (black line) and the corresponding fragment contributions (red, blue and green lines), (b and e) experimental and ( $\mathrm{c}$ and $\mathrm{f}$ ) theoretical cross sections of the cluster $\mathrm{Br}\left(\mathrm{CH}_{2}\right)_{m} \mathrm{COO} \cdot \mathrm{Br}\left(\mathrm{CH}_{2}\right)_{m} \mathrm{COOH}^{-}$with $m=4$ and $m=7$. In (d), the Br${ }^{-}$and $\mathrm{Br}\left(\mathrm{CH}_{2}\right)_{7} \mathrm{COOH} \cdot \mathrm{Br}^{-}$fragments are superimposed at $1500-1750 \mathrm{~cm}^{-1}$. Calculated at the B3LYP/def2TZVP level of theory.

regions, the respective wavenumber range is noted in the table. Note that for $m=3$, the $\mathrm{Br}\left(\mathrm{CH}_{2}\right)_{3} \mathrm{COOH} \cdot \mathrm{Br}\left(\mathrm{CH}_{2}\right)_{3} \mathrm{COO}^{-}$ precursor could not be obtained in the experiment; the spectrum for $m=10$ is shown in the ESI, $\dagger$ Fig. S4 and S5. The kinetics for $m=4,7,10$ are shown in Fig. S6-S8 (ESI $\dagger$ ).

Three different fragments are observed: $\mathrm{Br}\left(\mathrm{CH}_{2}\right)_{m} \mathrm{COO}^{-}$ is obviously formed by loss of neutral $\mathrm{Br}\left(\mathrm{CH}_{2}\right)_{m} \mathrm{COOH}$, while $\mathrm{Br}^{-}$and $\mathrm{Br}\left(\mathrm{CH}_{2}\right)_{m} \mathrm{COOH} \cdot \mathrm{Br}^{-}$suggest lactone formation upon IRMPD, see Table 1. For $m=4$, the by far dominant IRMPD fragment is $\mathrm{Br}\left(\mathrm{CH}_{2}\right)_{4} \mathrm{COOH} \cdot \mathrm{Br}^{-}$, the eliminated $\left(\mathrm{CH}_{2}\right)_{4} \mathrm{OCO}$ is most likely valerolactone. Scheme 1 depicts the mechanism of the $\mathrm{S}_{\mathrm{N}} 2$ reaction that transforms $\mathrm{Br}\left(\mathrm{CH}_{2}\right)_{4} \mathrm{COO}^{-}$to $\left(\mathrm{CH}_{2}\right)_{4} \mathrm{OCO}+$ $\mathrm{Br}^{-}$. Although the alternative reaction, decarboxylation and $\left(\mathrm{CH}_{2}\right)_{4}$ cyclobutane formation is thermochemically slightly favored with a reaction energy of $\Delta E=34 \mathrm{~kJ} \mathrm{~mol}^{-1}$, calculations indicate a high barrier of $168 \mathrm{~kJ} \mathrm{~mol}^{-1}$ in $\mathrm{Br}\left(\mathrm{CH}_{2}\right)_{4} \mathrm{COO}^{-}$due to an energetically demanding charge transfer. Valerolactone is therefore the most plausible product. The bromide fragment appears selectively around $2600-3000 \mathrm{~cm}^{-1}$ where high photon energies and high laser power provide more energy to trigger secondary reactions, in this case lactone formation followed by dissociation of the non-covalent $\mathrm{Br}\left(\mathrm{CH}_{2}\right)_{4} \mathrm{COOH} \cdot \mathrm{Br}^{-}$complex. 
a)
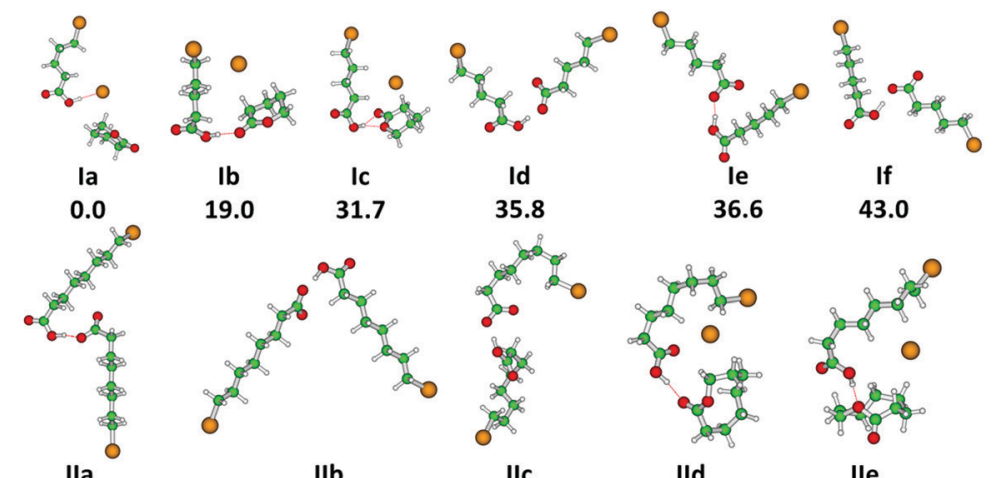

b)

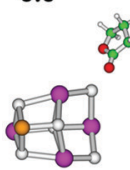

IIIa

0.0

0.6

15.9

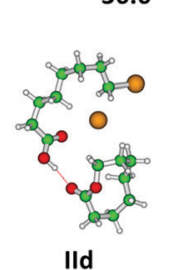

43.0

c)

$27.9 \quad 29.1$
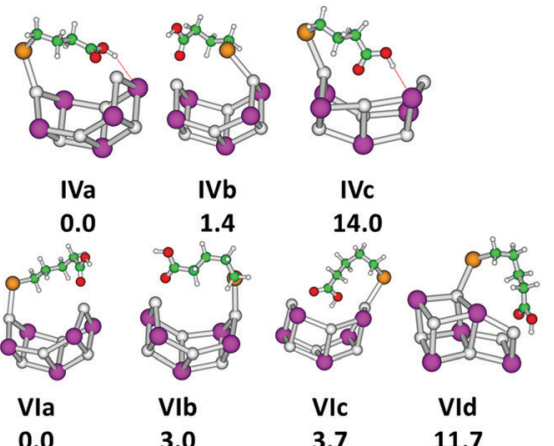

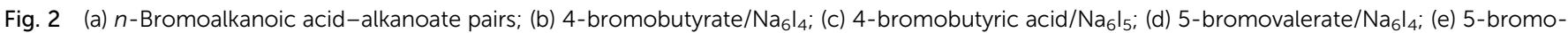

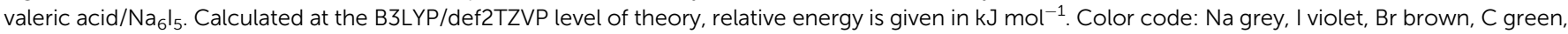
$\mathrm{O}$ red, $\mathrm{H}$ white.

Table 1 Intensity of fragmentation channels of $n$-bromoalkanoic acid and $n$-bromoalkanoates, $n=5,7$, of the anionic complexes $\mathrm{Br}\left(\mathrm{CH}_{2}\right)_{m} \mathrm{COOH}$. $\mathrm{Br}\left(\mathrm{CH}_{2}\right)_{m} \mathrm{COO}^{-}$and in salt environment for $m=3,4$ along with reaction energies $\Delta E$ calculated at the B3LYP/def2TZVP level of theory with respect to the most stable parent ion (Fig. 2). For the alkanoate/alkanoic acid-salt clusters, only the fragmentation channels with a branching ratio $>4 \%$ are shown, see Table S1 (ESI) for the complete listing

\begin{tabular}{|c|c|c|c|c|c|}
\hline Parent ion & Products & $\Delta E\left[\mathrm{~kJ} \mathrm{~mol}{ }^{-1}\right]$ & $\operatorname{IR}^{a}[\%]$ & $\operatorname{IR} 2^{b}[\%]$ & $\operatorname{IR} 3^{c}[\%]$ \\
\hline \multirow[t]{3}{*}{$\mathrm{Br}\left(\mathrm{CH}_{2}\right)_{4} \mathrm{COOH} \cdot \mathrm{Br}\left(\mathrm{CH}_{2}\right)_{4} \mathrm{COO}^{-}$} & $\mathrm{Br}^{-}+\left(\mathrm{CH}_{2}\right)_{4} \mathrm{COO} \cdot \mathrm{Br}\left(\mathrm{CH}_{2}\right)_{4} \mathrm{COOH}$ & 114 & - & 1.1 & 5.2 \\
\hline & $\mathrm{Br}\left(\mathrm{CH}_{2}\right)_{4} \mathrm{COOH} \cdot \mathrm{Br}^{-}+\left(\mathrm{CH}_{2}\right)_{4} \mathrm{OCO}$ & 42 & - & 98.5 & 94.8 \\
\hline & $\mathrm{Br}\left(\mathrm{CH}_{2}\right)_{4} \mathrm{COO}^{-}+\mathrm{Br}\left(\mathrm{CH}_{2}\right)_{4} \mathrm{COOH}$ & 90 & - & 0.4 & - \\
\hline \multirow[t]{3}{*}{$\mathrm{Br}\left(\mathrm{CH}_{2}\right)_{7} \mathrm{COOH} \cdot \mathrm{Br}\left(\mathrm{CH}_{2}\right)_{7} \mathrm{COO}^{-}$} & $\mathrm{Br}^{-}+\left(\mathrm{CH}_{2}\right)_{7} \mathrm{COO} \cdot \mathrm{Br}\left(\mathrm{CH}_{2}\right)_{7} \mathrm{COOH}$ & 61 & - & 11.6 & 28.6 \\
\hline & $\mathrm{Br}\left(\mathrm{CH}_{2}\right)_{7} \mathrm{COOH} \cdot \mathrm{Br}^{-}+\left(\mathrm{CH}_{2}\right)_{7} \mathrm{OCO}$ & 34 & - & 7.5 & - \\
\hline & $\mathrm{Br}\left(\mathrm{CH}_{2}\right)_{7} \mathrm{COO}^{-}+\mathrm{Br}\left(\mathrm{CH}_{2}\right)_{7} \mathrm{COOH}$ & 76 & - & 80.9 & 71.4 \\
\hline \multirow[t]{3}{*}{$\mathrm{Na}_{6} \mathrm{I}_{4}\left(\mathrm{Br}\left(\mathrm{CH}_{2}\right)_{3} \mathrm{COO}\right)^{+}$} & $\mathrm{Na}_{6} \mathrm{I}_{4} \mathrm{Br}^{+}+\left(\mathrm{CH}_{2}\right)_{3} \mathrm{OCO}$ & 99 & 88.2 & 100 & 94.5 \\
\hline & $\mathrm{Na}_{2} \mathrm{Br}^{+}+(\mathrm{NaI})_{4}\left(\mathrm{CH}_{2}\right)_{3} \mathrm{COO}$ & 174 & 4.4 & - & - \\
\hline & $\mathrm{Na}_{2} \mathrm{I}^{+}+\mathrm{Na}_{4} \mathrm{I}_{3}\left(\mathrm{Br}\left(\mathrm{CH}_{2}\right)_{3} \mathrm{COO}\right)$ & 178 & 4.9 & - & 3.0 \\
\hline \multirow[t]{2}{*}{$\mathrm{Na}_{6} \mathrm{I}_{5}\left(\mathrm{Br}\left(\mathrm{CH}_{2}\right)_{3} \mathrm{COOH}\right)^{+}$} & $\mathrm{Na}_{6} \mathrm{I}_{4}\left(\mathrm{Br}\left(\mathrm{CH}_{2}\right)_{3} \mathrm{COO}\right)^{+}+\mathrm{HI}$ & $14 / 77^{d}$ & 38.5 & 29.5 & 26.5 \\
\hline & $\mathrm{Na}_{6} \mathrm{I}_{5}^{+}+\mathrm{Br}\left(\mathrm{CH}_{2}\right)_{3} \mathrm{COOH}$ & 99 & 60.3 & 70.5 & 73.5 \\
\hline \multirow[t]{3}{*}{$\mathrm{Na}_{6} \mathrm{I}_{4}\left(\mathrm{Br}\left(\mathrm{CH}_{2}\right)_{4} \mathrm{COO}\right)^{+}$} & $\mathrm{Na}_{6} \mathrm{I}_{4} \mathrm{Br}^{+}+\left(\mathrm{CH}_{2}\right)_{4} \mathrm{OCO}$ & 104 & 71.0 & 90.7 & 69.0 \\
\hline & $\mathrm{Na}_{2} \mathrm{I}^{+}+\mathrm{Na}_{4} \mathrm{I}_{3}\left(\mathrm{Br}\left(\mathrm{CH}_{2}\right)_{4} \mathrm{COO}\right)$ & 222 & 29.1 & - & - \\
\hline & $\mathrm{Na}_{4} \mathrm{I}_{2}\left(\mathrm{Br}\left(\mathrm{CH}_{2}\right)_{4} \mathrm{COO}\right)^{+}+(\mathrm{NaI})_{2}$ & 183 & - & 9.3 & 28.6 \\
\hline \multirow[t]{3}{*}{$\mathrm{Na}_{6} \mathrm{I}_{5}\left(\mathrm{Br}\left(\mathrm{CH}_{2}\right)_{4} \mathrm{COOH}\right)^{+}$} & $\mathrm{Na}_{6} \mathrm{I}_{4}\left(\mathrm{Br}\left(\mathrm{CH}_{2}\right)_{4} \mathrm{COO}\right)^{+}+\mathrm{HI}$ & $27 / 72^{d}$ & 85.0 & 89.9 & 75.0 \\
\hline & $\mathrm{Na}_{6} \mathrm{I}_{4} \mathrm{Br}^{+}+\mathrm{HI}+\left(\mathrm{CH}_{2}\right)_{4} \mathrm{OCO}$ & 130 & 6.5 & - & 1.4 \\
\hline & $\mathrm{Na}_{6} \mathrm{I}_{5}^{+}+\mathrm{Br}\left(\mathrm{CH}_{2}\right)_{4} \mathrm{COOH}$ & 105 & 8.5 & 8.3 & 23.0 \\
\hline
\end{tabular}

${ }^{a} 833-1500 \mathrm{~cm}^{-1}$ for salt environment. ${ }^{b} 1000-2200 \mathrm{~cm}^{-1}$ for anionic complexes; $1600-1800 \mathrm{~cm}^{-1}$ for salt environment. ${ }^{c} 2200-4000 \mathrm{~cm}^{-1}$ for anionic complexes; $2600-4000 \mathrm{~cm}^{-1}$ for salt environment. ${ }^{d}$ Reaction energies for a cluster with/without lactone formation.

In line with experiment, the calculated reaction energies in Table 1 predict formation of $\mathrm{Br}\left(\mathrm{CH}_{2}\right)_{4} \mathrm{COOH} \cdot \mathrm{Br}^{-}$to be the most probable channel; evaporation of the pre-formed lactone requires only $42 \mathrm{~kJ} \mathrm{~mol}^{-1}$. Other channels lie considerably higher in energy.
The main fragment observed for $m=7$ is $\mathrm{Br}\left(\mathrm{CH}_{2}\right)_{7} \mathrm{COO}^{-}$with evaporation of $\mathrm{Br}\left(\mathrm{CH}_{2}\right)_{7} \mathrm{COOH}$, while $\mathrm{Br}^{-}$and $\mathrm{Br}\left(\mathrm{CH}_{2}\right)_{7} \mathrm{COOH} \cdot \mathrm{Br}^{-}$ are present only in minor amounts. $\mathrm{Br}^{-}$is observed again selectively around $2900 \mathrm{~cm}^{-1}$, while both $\mathrm{Br}^{-}$and $\mathrm{Br}\left(\mathrm{CH}_{2}\right)_{7} \mathrm{COOH} \cdot \mathrm{Br}^{-}$ appear almost with the same yield at $1500-1750 \mathrm{~cm}^{-1}$. 


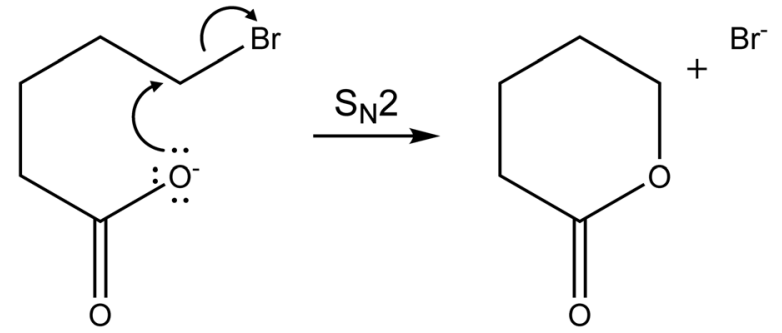

Scheme 1 Formation of valerolactone via an intramolecular $\mathrm{S}_{\mathrm{N}} 2$ reaction from $\mathrm{Br}\left(\mathrm{CH}_{2}\right)_{4} \mathrm{COO}^{-}$.

The calculated energies, Table 1, indicate that lactone is not present in major amounts on the cluster, as it would be eliminated preferentially, requiring $34 \mathrm{~kJ} \mathrm{~mol}^{-1}$, followed by $\mathrm{Br}^{-}$production as the second most important channel. Instead, $\mathrm{Br}\left(\mathrm{CH}_{2}\right)_{7} \mathrm{COO}^{-}$is formed from $\mathrm{Br}\left(\mathrm{CH}_{2}\right)_{7} \mathrm{COOH} \cdot \mathrm{Br}\left(\mathrm{CH}_{2}\right)_{7} \mathrm{COO}^{-}$ in the experiment, with a dissociation energy of $76 \mathrm{~kJ} \mathrm{~mol}^{-1}$.

Analysis of the IR spectra supports the conclusions drawn on a thermochemical basis. The calculated isomers can be discriminated based on the position of the $\mathrm{O}-\mathrm{H}$ stretch vibration. For $m=4$, the broad absorption at $2200-2600 \mathrm{~cm}^{-1}$ is assigned to the $\mathrm{O}-\mathrm{H}$ stretching mode shifted by the interaction with the $\mathrm{COO}^{-}$group of the alkanoate in isomers Id-f. The tail of the spectrum at $3100-3600 \mathrm{~cm}^{-1}$, however, can be assigned to the interaction of the $\mathrm{O}-\mathrm{H}$ group hydrogen bonded in the lactone complexes Ia-c and $\mathrm{C}-\mathrm{H}$ stretching vibrations. The peak positions in the fingerprint region of $1100-1700 \mathrm{~cm}^{-1}$ support the presence of both Ia-c and Id-f isomer classes. However, no specific isomers can be assigned here. The peak centered at $1606 \mathrm{~cm}^{-1}$ is likely due to isomers Id-f, see also Fig. S5 (ESI $\dagger$ ) for a zoom in the fingerprint region. The observed fragmentation can be induced by only one photon. The calculated and experimental cross sections, Fig. $1 \mathrm{~b}$ and $\mathrm{c}$, differ by one to two orders of magnitude, which we attribute in part to the high structural flexibility of the alkanoic acid/alkanoate-system, in particular the extreme broadening of the $\mathrm{O}-\mathrm{H}$ stretching mode upon hydrogen bonding to the carboxylate group, which goes along with efficient energy redistribution. Radiative cooling may also contribute to the low experimental IRMPD yield.

In the IR spectrum for $m=7$, the noise in the high-energy region above $3000 \mathrm{~cm}^{-1}$ is too high to identify or rule out the presence of octalactone based on the $\mathrm{O}-\mathrm{H}$ vibrations. Besides the dominant evaporation of the intact acid, the fragments indicating lactone elimination, $\mathrm{Br}^{-}$and $\mathrm{Br}\left(\mathrm{CH}_{2}\right)_{7} \mathrm{COOH} \cdot \mathrm{Br}^{-}$, are observed. All features in the spectrum can be assigned to isomer IIa without lactone. While there is an overlap with isomers containing lactone at the absorptions around $3000 \mathrm{~cm}^{-1}$ and $1700 \mathrm{~cm}^{-1}$, the calculated intense $\mathrm{O}-\mathrm{H}$ stretch features of isomers IId,e at $3300-3400 \mathrm{~cm}^{-1}$ are missing in the experimental spectrum. Thus, the lactone containing isomers IId,e are at most a minor fraction of the experimental mixture. According to the calculated thermochemistry, at least two photons are required to induce the observed fragmentation; the experimental and calculated absorption cross sections differ again by two orders of magnitude.
IRMPD of $\boldsymbol{n}$-bromoalkanoic acids and $\boldsymbol{n}$-bromoalkanoates in salt environment $(n=4,5,8,11)$

To investigate the influence of a salt environment on the potential lactone formation, sodium iodide clusters were prepared by ESI, where one $\mathrm{I}^{-}$ion was replaced by a bromoalkanoate ion. Sodium iodide clusters doped with a neutral molecule of bromoalkanoic acid were studied for comparison. Table 1 shows the reaction energies and branching ratios of the fragments with an intensity above $4 \%$, the detailed breakdown of all observed fragments is given in Table S1 (ESI $\dagger$ ). Fig. 3 shows the absorption spectrum of $\mathrm{Na}_{6} \mathrm{I}_{4}\left(\mathrm{Br}\left(\mathrm{CH}_{2}\right)_{3} \mathrm{COO}\right)^{+}$and $\mathrm{Na}_{6} \mathrm{I}_{5}\left(\mathrm{Br}\left(\mathrm{CH}_{2}\right)_{3} \mathrm{COOH}\right)^{+}$in the $833-3846 \mathrm{~cm}^{-1}$ region. The spectra for $\mathrm{Na}_{6} \mathrm{I}_{4}\left(\mathrm{Br}\left(\mathrm{CH}_{2}\right)_{3} \mathrm{COO}\right)^{+}$were measured with $15 \mathrm{~s}$ (region IR1), $7 \mathrm{~s}$ (region IR2) and $5 \mathrm{~s}$ (region IR3) irradiation time, while the ones for $\mathrm{Na}_{6} \mathrm{I}_{5}\left(\mathrm{Br}\left(\mathrm{CH}_{2}\right)_{3} \mathrm{COOH}\right)^{+}$were measured with $15 \mathrm{~s}$ (region IR1), $6 \mathrm{~s}$ (region IR2) and $3 \mathrm{~s}$ (region IR3). The calculated structures of the most stable isomers are illustrated in Fig. 2b-e. For the $\mathrm{Na}_{6} \mathrm{I}_{4}\left(\mathrm{Br}\left(\mathrm{CH}_{2}\right)_{3} \mathrm{COO}\right)^{+}$ion, the most intense fragmentation channel over the whole spectral range is $\mathrm{Na}_{6} \mathrm{I}_{4} \mathrm{Br}^{+}$, which indicates butyrolactone elimination from the cluster. In line with this interpretation, the most stable structure of $\mathrm{Na}_{6} \mathrm{I}_{4}\left(\mathrm{Br}\left(\mathrm{CH}_{2}\right)_{3} \mathrm{COO}\right)^{+}$is $\mathrm{Na}_{6} \mathrm{I}_{4} \mathrm{Br}^{+}$with $\left(\mathrm{CH}_{2}\right)_{3} \mathrm{OCO}$ non-covalently attached, isomer IIIa in Fig. $2 \mathrm{~b}$. Since structures with a bromobutyrate moiety lie significantly higher in energy, isomer IIIa is also the most likely structure to appear in the experiment. The kinetics suggests that lactone elimination is a primary process (Fig. S10, ESI $\dagger$ ).

The peaks at $2938 \mathrm{~cm}^{-1}$ and $3013 \mathrm{~cm}^{-1}$ do not allow for an unambiguous assignment of isomers, since $\mathrm{C}-\mathrm{H}$ absorptions are only moderately influenced by the cluster structure. The observed features are consistent with any of the three calculated isomers, or a mixture of them. However, the sharp $\mathrm{C}-\mathrm{O}$ stretch peak at $1761 \mathrm{~cm}^{-1}$, the missing absorption at $1540 \mathrm{~cm}^{-1}$ and the absorptions at 1195, 1032 and $987 \mathrm{~cm}^{-1}$ are consistent with the dominant presence of isomer IIIa. This indicates that butyrolactone is formed in the electrospray process, before the clusters are stored in the ICR cell and heated by IR irradiation.

The dissociation into $\mathrm{Na}_{6} \mathrm{I}_{4} \mathrm{Br}^{+}$, observed as the main reaction channel in the experiment, requires $99 \mathrm{~kJ} \mathrm{~mol}^{-1}$, Table 1. This implies that about two photons are needed in the 2903-3040 $\mathrm{cm}^{-1}$ region and four to five photons in the fingerprint region. The absolute values of the experimental and theoretical cross section derived using this assumption (Fig. 3b and c) match well in the $\mathrm{C}-\mathrm{H}$ stretch region, while the deviation is about an order of magnitude in the fingerprint region. Due to the low laser power in this region and the large number of degrees of freedom, irradiation times are long, which favors radiative cooling. This effect is not accounted for in our multiple photon analysis.

When neutral bromobutyric acid is attached to the sodium iodide cluster, resulting in $\mathrm{Na}_{6} \mathrm{I}_{5}\left(\mathrm{Br}\left(\mathrm{CH}_{2}\right)_{3} \mathrm{COOH}\right)^{+}$, the most intense fragmentation channel corresponds to evaporation of the intact 4-bromobutyric acid molecule from the cluster, evidenced by the detection of $\mathrm{Na}_{6} \mathrm{I}_{5}{ }^{+}$(see Fig. 3d-f for the spectra, Table 1 for the reaction energies and Fig. S11 (ESI $\dagger$ ) 


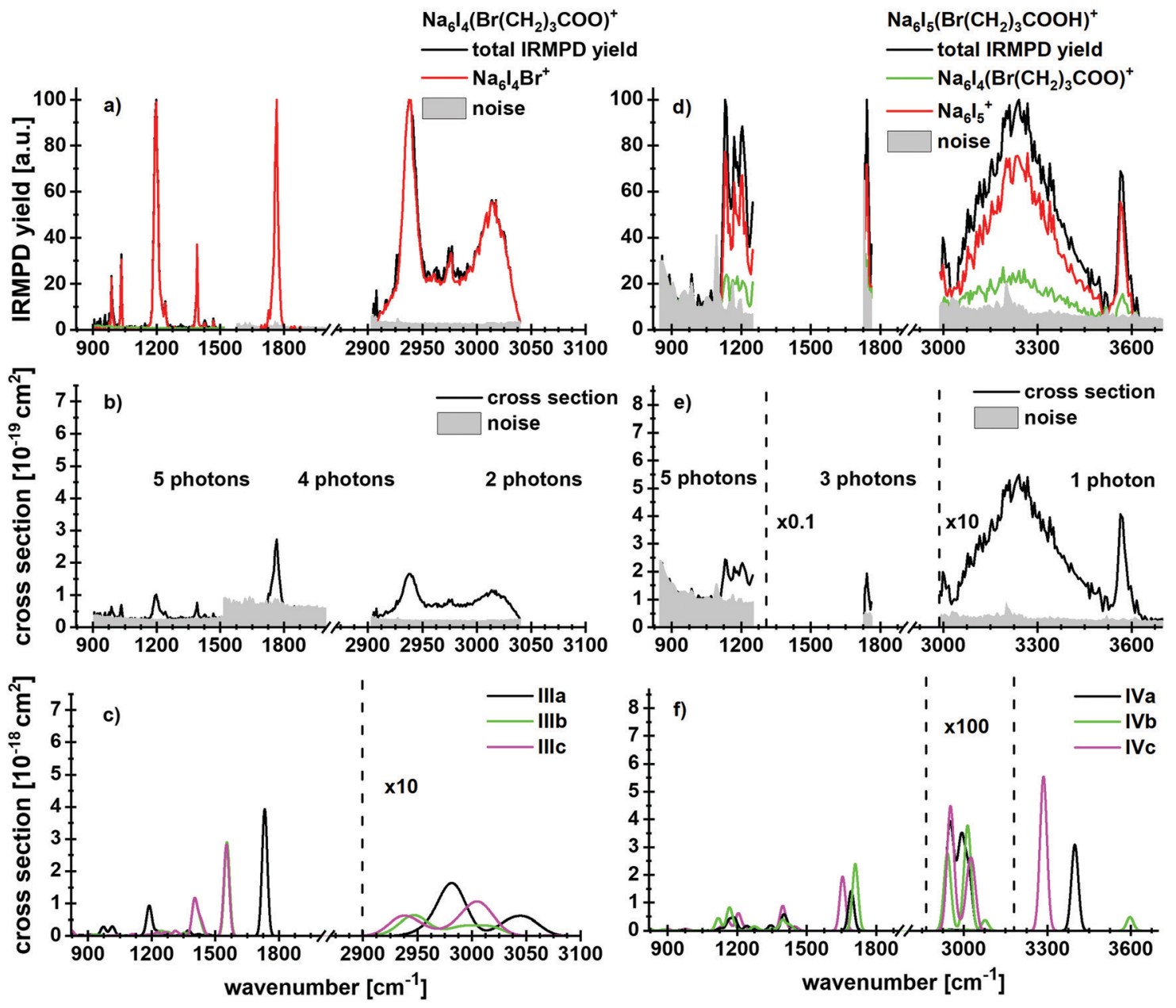

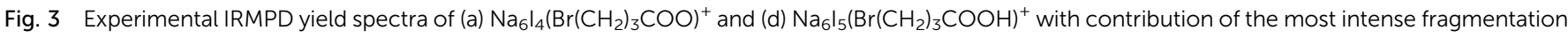
products. (b and e) Multiphoton photodissociation cross sections derived from (a and d). (c and f) Calculated spectra in harmonic approximation for $\mathrm{Na}_{6} \mathrm{I}_{4}\left(\mathrm{Br}\left(\mathrm{CH}_{2}\right)_{3} \mathrm{COO}\right)^{+}$and $\mathrm{Na}_{6} \mathrm{I}_{5}\left(\mathrm{Br}_{(}\left(\mathrm{CH}_{2}\right)_{3} \mathrm{COOH}\right)^{+}$, respectively, for $833-3846 \mathrm{~cm}^{-1}$. Here, the regions measured in detail are shown. The overview spectra are provided in Fig. S2 (ESI†). The theoretical spectra are scaled with a factor of 0.97.

for the kinetics). The second most intense channel is $\mathrm{HI}$ elimination. Evaporation of 4-bromobutyric acid or HI requires $99 \mathrm{~kJ} \mathrm{~mol}^{-1}$ or $77 \mathrm{~kJ} \mathrm{~mol}^{-1}$, respectively. Following HI elimination, the remaining bromobutyrate affords lactone formation, which reduces the overall reaction energy to $14 \mathrm{~kJ} \mathrm{~mol}^{-1}$. However, both $\mathrm{HI}$ elimination and lactone formation are hindered by barriers (see also below). We note that HI release was already observed in a previous study where cesium iodide clusters were doped with small peptides. ${ }^{60}$ In both cases, HI elimination probably follows a similar mechanism as the release of $\mathrm{HCl}$ from a bulk sea-salt surface following uptake of $\mathrm{HNO}_{3}$, which was reported by Haan and Finlayson-Pitts. ${ }^{65}$

The IR spectrum shows that the cluster is present in several conformations. For example, in the $\mathrm{O}-\mathrm{H}$ stretching region, the peak at $3569 \mathrm{~cm}^{-1}$ results from a free $\mathrm{O}-\mathrm{H}$ vibration (e.g. in isomer IVb), whereas the broad absorption centered at $3241 \mathrm{~cm}^{-1}$ is induced by the $\mathrm{OH} \cdots \mathrm{I}^{-}$interaction (isomers IVa and IVc). In the $2800-3000 \mathrm{~cm}^{-1}$ region, C-H vibrations contribute to the experimental spectral intensity. For the fragmentation in this wavelength region, at least one photon is needed. The peak at
$1739 \mathrm{~cm}^{-1}$ points towards isomer IVb or similar conformations, with at least three photons needed for the dissociation. The experimental and theoretical cross section values are comparable in this region. Since the signal and the absorption around $1200 \mathrm{~cm}^{-1}$ were very weak, no assignment to a specific isomer is possible.

Fig. 4 shows experimental and calculated IR spectra of $\mathrm{Na}_{6} \mathrm{I}_{4}\left(\mathrm{Br}\left(\mathrm{CH}_{2}\right)_{4} \mathrm{COO}\right)^{+}$and $\mathrm{Na}_{6} \mathrm{I}_{5}\left(\mathrm{Br}\left(\mathrm{CH}_{2}\right)_{4} \mathrm{COOH}\right)^{+}$. The spectra for $\mathrm{Na}_{6} \mathrm{I}_{4}\left(\mathrm{Br}\left(\mathrm{CH}_{2}\right)_{4} \mathrm{COO}\right)^{+}$were measured with $20 \mathrm{~s}$ (region IR1), $10 \mathrm{~s}$ (region IR2) and $3 \mathrm{~s}$ (region IR3) irradiation time, the irradiation times for $\mathrm{Na}_{6} \mathrm{I}_{5}\left(\mathrm{Br}\left(\mathrm{CH}_{2}\right)_{4} \mathrm{COOH}\right)^{+}$were $10 \mathrm{~s}$ (region IR1), $10 \mathrm{~s}$ (region IR2) and $3 \mathrm{~s}$ (region IR3). For 5-bromovalerate complexed with salt, several different fragmentation patterns are observed (Table 1), where the dominant fragment $\mathrm{Na}_{6} \mathrm{I}_{4} \mathrm{Br}^{+}$ is consistent with valerolactone elimination. In lower yields, $\mathrm{Na}_{2} \mathrm{I}^{+}$and $\mathrm{Na}_{4} \mathrm{I}_{2}\left(\mathrm{Br}\left(\mathrm{CH}_{2}\right)_{4} \mathrm{COO}\right)^{+}$are observed. $\mathrm{Na}_{4} \mathrm{I}_{2} \mathrm{Br}^{+}$appears with less intensity and may be created during secondary reactions. The most stable structure in Fig. 2d, isomer Va, shows that lactone formation is again energetically preferred.

In contrast to 4-bromobutyrate, both the valerolactone and 5-bromovalerate seem to be present in the experimental ion 

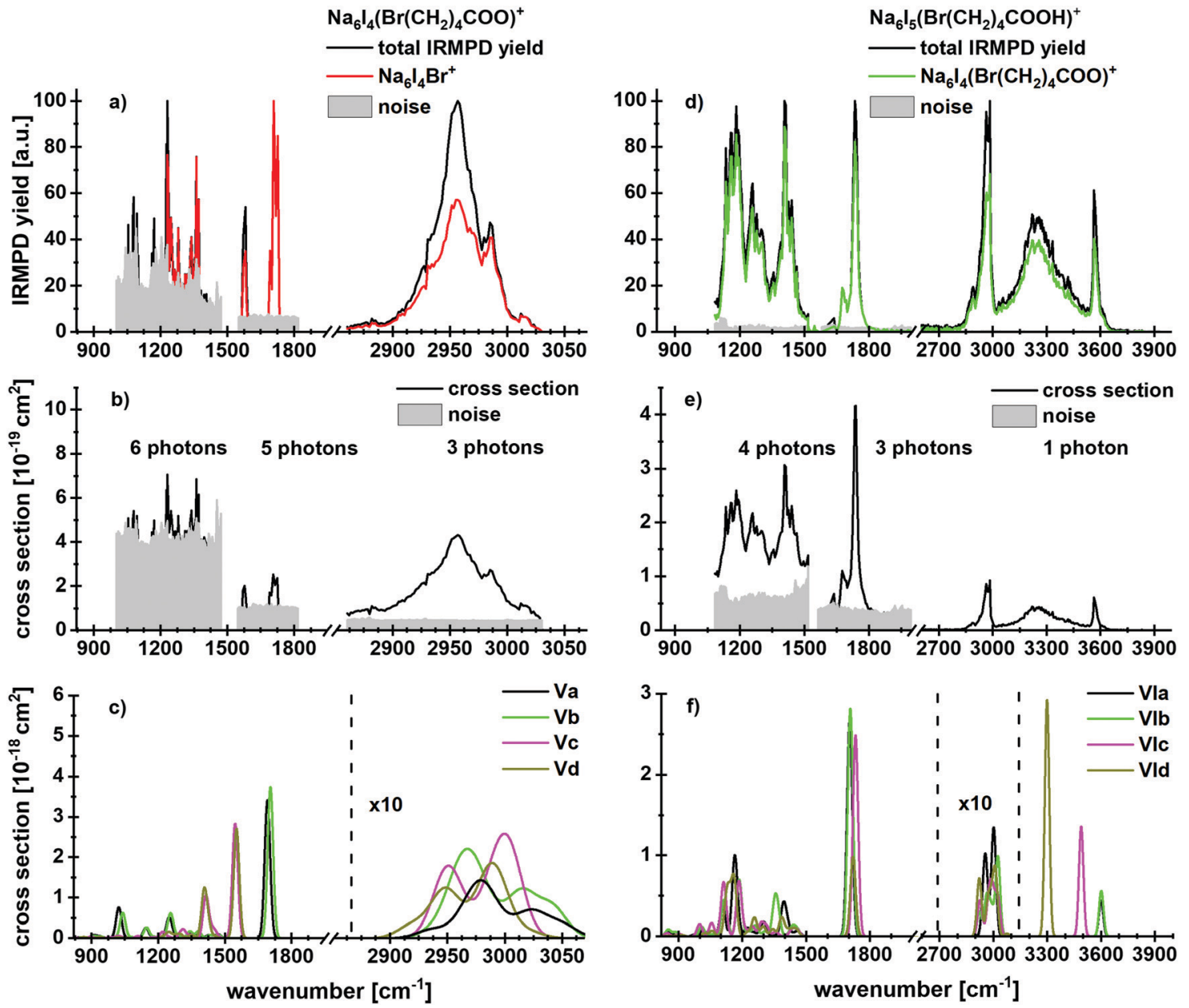

Fig. 4 Experimental IRMPD yield spectra of (a) $\mathrm{Na}_{6} \mathrm{I}_{4}\left(\mathrm{Br}\left(\mathrm{CH}_{2}\right)_{4} \mathrm{COO}\right)^{+}$and (d) $\mathrm{Na}_{6} \mathrm{I}_{5}\left(\mathrm{Br}\left(\mathrm{CH}_{2}\right)_{4} \mathrm{COOH}\right)^{+}$with contribution of the most intense fragmentation products. ( $b$ and e) Multiphoton photodissociation cross sections derived from (a and d). (c and f) Calculated spectra in harmonic approximation for $\mathrm{Na}_{6} \mathrm{I}_{4}\left(\mathrm{Br}\left(\mathrm{CH}_{2}\right)_{4} \mathrm{COO}\right)^{+}$and $\mathrm{Na}_{6} \mathrm{I}_{5}\left(\mathrm{Br}\left(\mathrm{CH}_{2}\right)_{4} \mathrm{COOH}\right)^{+}$, respectively, for $833-3846 \mathrm{~cm}^{-1}$. Here, the regions measured in detail are shown. The overview spectra are provided in Fig. S3 (ESI + ). The theoretical spectra are scaled with a factor of 0.97 .

population, evidenced by the peaks in the $\mathrm{C}-\mathrm{O}$ stretch region. The lactone structure (isomers $\mathbf{V a}, \mathbf{b}$ ) is identified by the peak at $1712 \mathrm{~cm}^{-1}$. The presence of 5-bromovalerate (isomers $\mathbf{V c}, \mathbf{d}$ ) is responsible for the absorption at $1575 \mathrm{~cm}^{-1}$. Since the $\mathrm{Na}_{6} \mathrm{I}_{4} \mathrm{Br}^{+}$ fragment appears also following this excitation, we conclude that lactone is formed from 5-bromovalerate activated by IR light. The kinetics (Fig. S12, ESI $\dagger$ ) shows that lactone elimination is again a primary process. The kinetic fit requires absorption of multiple photons. The spectral features in the $\mathrm{C}-\mathrm{H}$ stretch region around $3000 \mathrm{~cm}^{-1}$ and the fingerprint region of $850-1480 \mathrm{~cm}^{-1}$ cannot be assigned to specific isomers. The theoretical and experimental cross sections are comparable in the $\mathrm{C}-\mathrm{H}$ and fingerprint region, while a difference of more than an order of magnitude is observed for the $\mathrm{C}-\mathrm{O}$ modes.

The spectrum and fragmentation behavior changes for 5-bromovaleric acid, see Fig. 4d-f. As also evident from the kinetics, Fig. S13 (ESI $\dagger$ ), the most intense fragmentation channel is the evaporation of $\mathrm{HI}$ from the cluster, with a low reaction energy of $72 \mathrm{~kJ} \mathrm{~mol}^{-1}$, or $27 \mathrm{~kJ} \mathrm{~mol}^{-1}$ if lactone is formed in parallel. Thus, at least one photon is needed for decomposition at 2540-3840 $\mathrm{cm}^{-1}$. The $\mathrm{Na}_{6} \mathrm{I}_{5}{ }^{+}$fragment appears as the second most abundant fragment, with a calculated reaction energy of $105 \mathrm{~kJ} \mathrm{~mol}^{-1}$. Interestingly, also $\mathrm{Na}_{6} \mathrm{I}_{4} \mathrm{Br}^{+}$is observed, which according to the fit is a secondary product. It is thus seamlessly explained as $\mathrm{HI}$ elimination followed by lactone formation and loss.

The absorption centered at $3564 \mathrm{~cm}^{-1}$ originates from a free $\mathrm{O}-\mathrm{H}$ vibration of the acid, the broad absorption at $3250 \mathrm{~cm}^{-1}$ again from the $\mathrm{OH}_{\cdots} \mathrm{I}^{-}$interaction. The doublet around $2970 \mathrm{~cm}^{-1}$ and a weak transition at $2886 \mathrm{~cm}^{-1}$ can be assigned to $\mathrm{C}-\mathrm{H}$ vibrations, based on the comparison with the spectrum in Fig. $4 \mathrm{a}$ and the calculations.

For the $\mathrm{C}-\mathrm{O}$ absorption observed at $1720 \mathrm{~cm}^{-1}, \mathrm{Na}_{6} \mathrm{I}_{4}\left(\mathrm{Br}\left(\mathrm{CH}_{2}\right)_{4^{-}}\right.$ $\mathrm{COO})^{+}$with $\mathrm{HI}$ elimination is the most intense fragmentation channel while $\mathrm{Na}_{6} \mathrm{I}_{5}{ }^{+}$appears with lower intensity. In the $1100-1500 \mathrm{~cm}^{-1}$ region, HI elimination is again the favored dissociation pathway. The absorption centered at $1400 \mathrm{~cm}^{-1}$ results from $\mathrm{CH}_{2}$ bending mode and indicates the presence of isomer VIa or VIb, showing a local absorption in this region. Two further peaks with similar intensities, induced by coupled 
$\mathrm{C}-\mathrm{C}$ and $\mathrm{C}-\mathrm{O}$ vibrations, again point out that more than one isomer is needed to interpret the IR spectrum.

The measurements were repeated with bromoalkanoates and bromoalkanoic acids with longer aliphatic chains. These experiments did not yield clear evidence for lactone formation. For 8-bromooctanoate, loss of $[\mathrm{NaI}]_{2}$ is the preferred fragmentation channel (Fig. S14, ESI $\dagger$ ), while no fragment that would correspond to lactone formation is present in the investigated IR region. Upon doping the salt cluster with intact 8-bromooctanoic acid, the dominant fragment channels are loss of $\mathrm{HI}$ competing with loss of the complete molecule.

In the case of 11-bromoundecanoate (Fig. S15 and S16, ESI $\dagger)$, loss of $[\mathrm{NaI}]_{2}$ again is the dominant reaction channel. Interestingly, the $\mathrm{C}-\mathrm{Br}$ bond becomes activated in these smaller salt

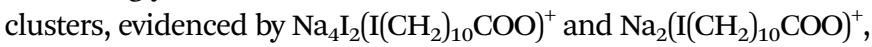
the dominant secondary fragments. Obviously, $\mathrm{I}^{-}$replaces $\mathrm{Br}^{-}$in an $S_{N} 2$ reaction. ${ }^{66}$ This is the reverse of the standard $S_{N} 2$ reaction, most likely mediated by the interaction with the salt. A fragment that could point to lactone formation, $\mathrm{Na}_{2} \mathrm{Br}^{+}$, appears late with low intensity. However, it is more likely formed by loss of $\mathrm{Na}_{2} \mathrm{I}\left(\mathrm{I}\left(\mathrm{CH}_{2}\right)_{10} \mathrm{COO}\right)$ from $\mathrm{Na}_{4} \mathrm{I}_{2}\left(\mathrm{Br}\left(\mathrm{CH}_{2}\right)_{10} \mathrm{COO}\right)^{+}$, which has already rearranged to $\mathrm{Na}_{4} \mathrm{IBr}\left(\mathrm{I}\left(\mathrm{CH}_{2}\right)_{10} \mathrm{COO}\right)^{+}$.

\section{Reaction paths for lactone formation}

The experimental observation of $\mathrm{Br}^{-}$ions, either bare, complexed to bromoalkanoic acid, or embedded in a $[\mathrm{NaI}]_{x}$ cluster, is evidence for lactone formation. To get a better idea how and when lactone formation is feasible in the experiment, we calculated the reaction path for $m=3,4$ and 7 in three model environments as shown in Fig. 5: bare bromoalkanoate, bromoalkanoate complexed with $\mathrm{Na}^{+}$, and a simplified bromoalkanoate-bromoalkanoic acid complex. For bare bromoalkanoate, the barrier increases monotonically along the $m=3$, 4, 7 series from $18 \mathrm{~kJ} \mathrm{~mol}^{-1}$ to $58 \mathrm{~kJ} \mathrm{~mol}^{-1}$. To get closer to the relevant barrier of lactone formation in the experiment, we repeated this calculation with a simplified model of the studied complex, the complex $\mathrm{Br}\left(\mathrm{CH}_{2}\right) \mathrm{COOH} \cdot \mathrm{Br}\left(\mathrm{CH}_{2}\right)_{m} \mathrm{COO}^{-}$in which the aliphatic chain of the neutral molecule was shortened to reduce both the conformational flexibility and the number of electrons. Here, one can expect a barrier of about 61 and $119 \mathrm{~kJ} \mathrm{~mol}^{-1}$ for lactone formation with $m=4$ and 7, respectively. Due to the high barrier for the longer chain, lactone formation in the isolated complex can be ruled out, since direct dissociation is both energetically preferred, Table 1 , and with a loose transition state also mechanistically favored. For $m=7$, fragments involving lactone elimination therefore most likely result from isomers IId,e formed in the ESI process. The kinetics for $m=7,10$ in Fig. S6 and S7 (ESI $\dagger$ ) also reveal that the potential lactone elimination takes place much less efficiently for longer alkanoate chains than for the complex with $m=4$, Fig. S8 (ESI $\dagger$ ), further hinting that the ring has to be present before irradiation. Lactone elimination is also induced by ambient black-body infrared radiation for $m=4$ with a very small rate of $0.006 \mathrm{~s}^{-1}$, see Fig. S9 (ESI $\dagger$ ) for the BIRD kinetics.

The lactone formation path for bromobutyrate and the bromobutyrate-sodium complex $\mathrm{NaBr}\left(\mathrm{CH}_{2}\right)_{3} \mathrm{COO}$ is provided in Fig. 5a. Compared to butyrolactone formation in the gas phase with a small barrier of $18 \mathrm{~kJ} \mathrm{~mol}^{-1}$ and exothermicity of $82 \mathrm{~kJ} \mathrm{~mol}^{-1}$, the presence of the $\mathrm{Na}^{+}$counterion increases the barrier to $124 \mathrm{~kJ} \mathrm{~mol}^{-1}$, since the interaction between the $\mathrm{CO}_{2}{ }^{-}$ group, $\mathrm{Br}$ and $\mathrm{Na}^{+}$stabilizes the reactant compared to the transition state structure. The reaction energy stays almost unaffected by the presence of $\mathrm{Na}^{+}$. This suggests that lactone formation takes place during the electrospray process, since complexation of bromobutyrate with the salt cluster increases the barrier and slows down the reaction.

For 5-bromovalerate, lactone formation faces a higher barrier and is less exothermic than for 4-bromobutyrate (Fig. 5a and b). Compared to the barrier in the gas phase of $24 \mathrm{~kJ} \mathrm{~mol}^{-1}$, the barrier increases to $141 \mathrm{~kJ} \mathrm{~mol}^{-1}$ when the ion complexes with $\mathrm{Na}^{+}$. This can explain the presence of both isomers in the experimental mixture. Lactones may be formed in the ESI source, with a slightly higher reaction barrier compared to 4-bromovalerate. The reaction is then hindered as soon as the organic ion is complexed with salt.

We found transition states for lactone formation for 8-bromooctanoate and 11-bromoundecanoate in the gas phase, with barriers of 58 and $44 \mathrm{~kJ} \mathrm{~mol}^{-1}$, respectively, about twice the value of 5-bromovalerate. We consider it highly unlikely to a)

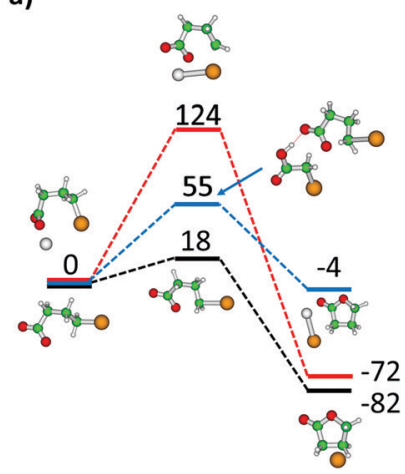

b)

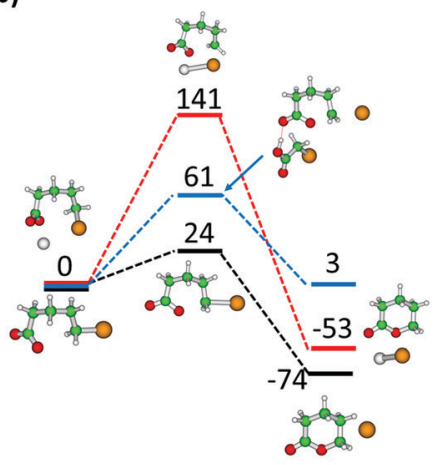

c)

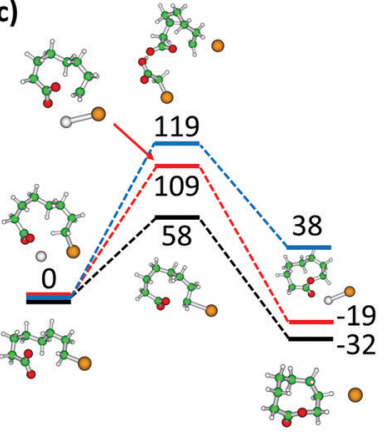

Fig. 5 Reaction path to form lactones from bromoalkanoate $\mathrm{Br}\left(\mathrm{CH}_{2}\right)_{m} \mathrm{COO}^{-}$in the gas phase (black curve), in the presence of a sodium ion $\mathrm{NaBr}\left(\mathrm{CH}_{2}\right)_{m} \mathrm{COO}$ (red curve) and in the $\mathrm{Br}\left(\mathrm{CH}_{2}\right) \mathrm{COOH} \cdot \mathrm{Br}\left(\mathrm{CH}_{2}\right)_{m} \mathrm{COO}^{-}$model complex (blue curve) for (a) $m=3$, (b) $m=4$, (c) $m=7$. Calculated at the $\mathrm{B} 3 \mathrm{LYP} / \mathrm{def2TZVP}$ level, energies are given in $\mathrm{kJ} \mathrm{mol}^{-1}$. Color code: $\mathrm{Na}$ grey, Br brown, $\mathrm{C}$ green, $\mathrm{O}$ red, $\mathrm{H}$ white. 
happen in the salt environment during IRMPD, as the long bromoalkyl chain has to be in the correct orientation to form the lactone ring, which is exceedingly improbable.

\section{Conclusion}

IRMPD of negatively charged complexes with $n$-bromoalkanoic acids $(n=5,8)$ clustered with the corresponding $n$-bromoalkanoates, as well as positively charged sodium iodide clusters doped with the intact acids and alkanoates $(n=4,5)$ was investigated experimentally and theoretically. The anionic complexes showed that lactone formation can be initiated by IR light for $n=5$, and some fragments indicating formation of rings were also observed for $n=8$. However, the formation via IR light is not expected for the latter case due to steric effects and a concomitant higher barrier, implying that a small fraction of clusters already contained lactone before irradiation. The failure to generate these complexes for $n=4$ by ESI suggests that lactone formation is even more facile for this small system, making the complex unstable under the experimental conditions.

The fragmentation behavior of the cationic salt clusters including an attached intact bromoalkanoic acid molecule shows the loss of $\mathrm{HI},[\mathrm{NaI}]_{x}$ and the intact acid. The situation changes for bromoalkanoates embedded in salt environment. Here, lactone evaporation was observed with 4-bromobutyrate, and the spectra suggest that butyrolactone is already present before irradiation of the cluster with laser light, formed during the ESI process. 5-Bromovalerate is slightly more stable, the valerolactone is formed both before and during laser irradiation. Experiment and calculations show that the salt environment tends to stabilize bromoalkanoates against lactone formation by increasing the barrier with respect to the free bromoalkanoate in the gas phase for 4-bromobutyrate and 5-bromovalerate.

In a real sea-salt aerosol, similar reaction mechanisms may be operative, albeit not driven by multiple infrared photons. Due to their larger size and the high-pressure environment in the atmosphere, they are efficiently thermalized. Reactions in the aerosol will be either thermally activated, or photochemically by visible or ultraviolet light. Moreover, sea-salt aerosols consist mainly of $\mathrm{NaCl}$, which will behave differently from the NaI clusters studied here. Nevertheless, our work shows that the barriers for thermally activated lactone formation from bromoalkanoates via an intramolecular $\mathrm{S}_{\mathrm{N}} 2$ reaction depend sensitively on the local environment of the carboxylate group and the bromine atom involved in the reaction. We suggest that this applies also to $\mathrm{S}_{\mathrm{N}} 2$ reactions in real sea-salt aerosols.

\section{Conflicts of interest}

There are no conflicts of interest to declare.

\section{Acknowledgements}

This work was supported by the Austrian Science Fund FWF within the DK-ALM: W1259-N27 and stand-alone project P28896.
The computational results presented have been achieved using the HPC infrastructure LEO of the University of Innsbruck. The tunable OPO systems are part of the Innsbruck Laser Core Facility, financed by the Austrian Federal Ministry of Education, Science and Research.

\section{References}

1 B. J. Finlayson-Pitts, Reactions at surfaces in the atmosphere: integration of experiments and theory as necessary (but not necessarily sufficient) for predicting the physical chemistry of aerosols, Phys. Chem. Chem. Phys., 2009, 11, 7760-7779.

2 M. O. Andreae, Atmospheric aerosols: biogeochemical sources and role in atmospheric chemistry, Science, 1997, 276, 1052-1058.

3 U. Pöschl, Atmospheric aerosols: composition, transformation, climate and health effects, Angew. Chem., 2005, 44, $7520-7540$.

4 S. J. Ghan and S. E. Schwartz, Aerosol properties and processes: a path from field and laboratory measurements to global climate models, Bull. Am. Meteorol. Soc., 2007, 88, 1059-1084.

$5 \mathrm{~J}$. Haywood and O. Boucher, Estimates of the direct and indirect radiative forcing due to tropospheric aerosols: a review, Rev. Geophys., 2000, 38, 513-543.

6 M. O. Andreae and D. Rosenfeld, Aerosol-cloud-precipitation interactions. Part 1. The nature and sources of cloudactive aerosols, Earth-Sci. Rev., 2008, 89, 13-41.

7 C. D. O'Dowd and G. de Leeuw, Marine aerosol production: a review of the current knowledge, Philos. Trans. R. Soc., A, 2007, 365, 1753-1774.

8 C. D. O'Dowd, M. H. Smith, I. E. Consterdine and J. A. Lowe, Marine aerosol, sea-salt, and the marine sulphur cycle: a short review, Atmos. Environ., 1997, 31, 73-80.

9 C. D. O'Dowd, M. C. Facchini, F. Cavalli, D. Ceburnis, M. Mircea, S. Decesari, S. Fuzzi, Y. J. Yoon and J.-P. Putaud, Biogenically driven organic contribution to marine aerosol, Nature, 2004, 431, 676-680.

10 A. I. Gogou, M. Apostolaki and E. G. Stephanou, Determination of organic molecular markers in marine aerosols and sediments: one-step flash chromatography compound class fractionation and capillary gas chromatographic analysis, J. Chromatogr. A, 1998, 799, 215-231.

11 D. Hansell, C. Carlson, D. Repeta and R. Schlitzer, Dissolved organic matter in the ocean: a controversy stimulates new insights, Oceanography, 2009, 22, 202-211.

12 A. Virkkula, K. Teinilä, R. Hillamo, V.-M. Kerminen, S. Saarikoski, M. Aurela, I. K. Koponen and M. Kulmala, Chemical size distributions of boundary layer aerosol over the atlantic ocean and at an antarctic site, J. Geophys. Res., 2006, 111, 21695.

13 A. Laskin, J. Laskin and S. A. Nizkorodov, Chemistry of atmospheric brown carbon, Chem. Rev., 2015, 115, 4335-4382. 
14 T. Lou and H. Xie, Photochemical alteration of the molecular weight of dissolved organic matter, Chemosphere, 2006, 65, 2333-2342.

15 D. B. Millet, M. Baasandorj, D. K. Farmer, J. A. Thornton, K. Baumann, P. Brophy, S. Chaliyakunnel, J. A. Gouw, M. de, Graus, L. Hu, A. Koss, B. H. Lee, F. D. LopezHilfiker, J. A. Neuman, F. Paulot, J. Peischl, I. B. Pollack, T. B. Ryerson, C. Warneke, B. J. Williams and J. Xu, A large and ubiquitous source of atmospheric formic acid, Atmos. Chem. Phys., 2015, 15, 6283-6304.

16 R. Fisseha, J. Dommen, M. Sax, D. Paulsen, M. Kalberer, R. Maurer, F. Höfler, E. Weingartner and U. Baltensperger, Identification of organic acids in secondary organic aerosol and the corresponding gas phase from chamber experiments, Anal. Chem., 2004, 76, 6535-6540.

17 R. Atkinson, Atmospheric chemistry of VOCs and NOx, Atmos. Environ., 2000, 34, 2063-2101.

18 I.-S. Kang, J. Xi and H.-Y. Hu, Photolysis and photooxidation of typical gaseous VOCs by UV irradiation: removal performance and mechanisms, Front. Environ. Sci. Eng., 2018, 12, 73.

19 S. N. Kozlov, V. L. Orkin, R. E. Huie and M. J. Kurylo, OH reactivity and UV spectra of propane, n-propyl bromide, and isopropyl bromide, J. Phys. Chem. A, 2003, 107, 1333-1338.

20 Y. L. Yung, J. P. Pinto, R. T. Watson and S. P. Sander, Atmospheric bromine and ozone perturbations in the lower stratosphere, J. Atmos. Sci., 1980, 37, 339-353.

21 M.-A. Sicre, J.-C. Marty and A. Saliot, n-Alkanes, fatty acid esters, and fatty acid salts in size fractionated aerosols collected over the mediterranean sea, J. Geophys. Res., 1990, 95, 3649.

22 P. Fu, K. Kawamura and K. Miura, Molecular characterization of marine organic aerosols collected during a roundthe-world cruise, J. Geophys. Res., 2011, 116, 482603.

23 B. R. T. Simoneit, Compound-specific carbon isotope analyses of individual long-chain alkanes and alkanoic acids in Harmattan aerosols, Atmos. Environ., 1997, 31, 2225-2233.

24 N. Yassaa, B. Youcef Meklati, A. Cecinato and F. Marino, Particulate n-alkanes, n-alkanoic acids and polycyclic aromatic hydrocarbons in the atmosphere of Algiers city area, Atmos. Environ., 2001, 35, 1843-1851.

25 S. Kurwadkar, Groundwater pollution and vulnerability assessment, Water Environ. Res., 2017, 89, 1561-1579.

26 A. D. McEachran, D. Shea, W. Bodnar and E. G. Nichols, Pharmaceutical occurrence in groundwater and surface waters in forests land-applied with municipal wastewater, Environ. Toxicol. Chem., 2016, 35, 898-905.

27 R. P. Schwarzenbach, T. Egli, T. B. Hofstetter, U. Gunten and B. von, Wehrli, Global water pollution and human health, Annu. Rev. Env. Resour., 2010, 35, 109-136.

28 P. J. Squillace, J. C. Scott, M. J. Moran, B. T. Nolan and D. W. Kolpin, VOCs, pesticides, nitrate, and their mixtures in groundwater used for drinking water in the United States, Environ. Sci. Technol., 2002, 36, 1923-1930.

29 Q. Sui, X. Cao, S. Lu, W. Zhao, Z. Qiu and G. Yu, Occurrence, sources and fate of pharmaceuticals and personal care products in the groundwater: a review, Emerging Contam., 2015, 1, 14-24.

30 R. A. Mandour, Human health impacts of drinking water (surface and ground) pollution Dakahlyia Governorate, Egypt, Appl. Water Sci., 2012, 2, 157-163.

31 M. Haseena, M. Faheem Malik, A. Javed, S. Arshad, N. Asif, S. Zulfiqar and J. Hanif, Water pollution and human health, Environ. Risk Assess. Rem., 2017, 01, 16-19.

32 Water challenges of an urbanizing world, ed. M. Glavan, InTech, 2018.

33 J. A. Camargo and A. Alonso, Ecological and toxicological effects of inorganic nitrogen pollution in aquatic ecosystems: a global assessment, Environ. Int., 2006, 32, 831-849.

34 K. Mohankumar, V. Hariharan and N. P. Rao, Heavy metal contamination in groundwater around industrial estate $v s$. residential areas in Coimbatore, India, J. Clin. Diagn. Res., 2016, 10, BC05-BC07.

35 D. J. Lapworth, N. Baran, M. E. Stuart and R. S. Ward, Emerging organic contaminants in groundwater: a review of sources, fate and occurrence, Environ. Pollut., 2012, 163, 287-303.

36 L. Lamastra, M. Balderacchi and M. Trevisan, Inclusion of emerging organic contaminants in groundwater monitoring plans, MethodsX, 2016, 3, 459-476.

37 C. Rosik-Dulewska, T. Ciesielczuk and M. Krysiński, Organic pollutants in groundwater in the former airbase, Arch. Environ. Prot., 2012, 38, 305.

38 B. C. J. Zoeteman, K. Harmsen, J. B. H. J. Linders, C. F. H. Morra and W. Slooff, Persistent organic pollutants in river water and ground water of the Netherlands, Chemosphere, 1980, 9, 231-249.

39 S. J. Nelson, M. Iskander, M. Volz, S. Khalifa and R. Haberman, Studies of DBCP in subsoils, Sci. Total Environ, 1981, 21, 35-40.

40 P. J. Isaacson, L. Hankin and C. R. Frink, Boiling drinking water removes ethylene dibromide, Science, 1984, 225, 672.

41 R. A. Weintraub, G. W. Jex and H. A. Moye, Chemical and microbial degradation of 1,2-dibromoethane (EDB) in Florida ground water, soil, and sludge, in Evaluation of pesticides in ground water, ed. W. Y. Garner, R. C. Honeycutt and H. N. Nigg, American Chemical Society, Washington, DC, 1986, vol. 315, pp. 294-310.

42 R. P. Schwarzenbach, W. Giger, C. Schaffner and O. Wanner, Groundwater contamination by volatile halogenated alkanes: abiotic formation of volatile sulfur compounds under anaerobic conditions, Environ. Sci. Technol., 1985, 19, 322-327.

43 F. Ferreira da Silva, N Varella do, M. T. Jones, N. C. Vrønning Hoffmann, S. Denifl, S. Bald and I. Kopyra, J. Electron-induced reactions in 3-bromopyruvic acid, Chem. - Eur. J., 2019, 25, 5498-5506.

44 T. M. Vogel and M. Reinhard, Reaction products and rates of disappearance of simple bromoalkanes, 1,2-dibromopropane, and 1,2-dibromoethane in water, Environ. Sci. Technol., 1986, 20, 992-997.

45 S. D. Richardson, Environmental mass spectrometry: emerging contaminants and current issues, Anal. Chem., 2010, 82, 4742-4774. 
46 D. J. Donaldson, A. F. Tuck and V. Vaida, Atmospheric photochemistry via vibrational overtone absorption, Chem. Rev., 2003, 103, 4717-4730.

47 J. Roithová, Characterization of reaction intermediates by ion spectroscopy, Chem. Soc. Rev., 2012, 41, 547-559.

48 N. Heine, T. I. Yacovitch, F. Schubert, C. Brieger, D. M. Neumark and K. R. Asmis, Infrared photodissociation spectroscopy of microhydrated nitrate-nitric acid clusters $\mathrm{NO}_{3}{ }^{-}\left(\mathrm{HNO}_{3}\right)_{m}\left(\mathrm{H}_{2} \mathrm{O}\right)_{n}$, J. Phys. Chem. A, 2014, 118, 7613-7622.

49 M. C. Thompson, J. Ramsay and J. M. Weber, Solvent-driven reductive activation of $\mathrm{CO}_{2}$ by bismuth: switching from metalloformate complexes to oxalate products, Angew. Chem., Int. Ed., 2016, 55, 15171-15174.

50 J. Oomens, D. T. Moore, G. Meijer and G. von Helden, Infrared multiple photon dynamics and spectroscopy of cationic PABA and its dehydroxylated fragment ion, Phys. Chem. Chem. Phys., 2004, 6, 710-718.

51 V. J. F. Lapoutre, B. Redlich, A. F. G. van der Meer, J. Oomens, J. M. Bakker, A. Sweeney, A. Mookherjee and P. B. Armentrout, Structures of the dehydrogenation products of methane activation by $5 \mathrm{~d}$ transition metal cations, J. Phys. Chem. A, 2013, 117, 4115-4126.

52 O. W. Wheeler, M. Salem, A. Gao, J. M. Bakker and P. B. Armentrout, Sequential activation of methane by $\mathrm{Ir}^{+}$: an IRMPD and theoretical investigation, Int. J. Mass Spectrom., 2019, 435, 78-92.

53 A. C. Hermes, S. M. Hamilton, W. S. Hopkins, D. J. Harding, C. Kerpal, G. Meijer, A. Fielicke and S. R. Mackenzie, Effects of coadsorbed oxygen on the infrared driven decomposition of $\mathrm{N}_{2} \mathrm{O}$ on isolated $\mathrm{Rh}_{5}{ }^{+}$clusters, J. Phys. Chem. Lett., 2011, 2, 3053-3057.

54 I. S. Parry, A. Kartouzian, S. M. Hamilton, O. P. Balaj, M. K. Beyer and S. R. Mackenzie, Chemical reactivity on gas-phase metal clusters driven by blackbody infrared radiation, Angew. Chem., Int. Ed., 2015, 54, 1357-1360.

55 T. F. Pascher, M. Ončák, C. van der Linde and M. K. Beyer, Release of formic acid from copper formate: hydride, proton-coupled electron and hydrogen atom transfer all play their role, ChemPhysChem, 2019, 20, 1420-1424.

56 T. F. Pascher, M. Ončák, C. van der Linde and M. K. Beyer, Decomposition of copper formate clusters: insight into elementary steps of calcination and carbon dioxide activation, ChemistryOpen, 2019, 8, 1453-1459.

57 A. Herburger, M. Ončák, C.-K. Siu, E. G. Demissie, J. Heller, W. K. Tang and M. K. Beyer, Infrared spectroscopy of sizeselected hydrated carbon dioxide radical anions $\mathrm{CO}_{2}{ }^{\bullet-}$ $\left(\mathrm{H}_{2} \mathrm{O}\right)_{n}(n=2-61)$ in the $\mathrm{C}-\mathrm{O}$ stretch region, Chem. - Eur. J., 2019, 25, 10165-10171.
58 E. Barwa, M. Ončák, T. F. Pascher, A. Herburger, C. van der Linde and M. K. Beyer, Infrared multiple photon dissociation spectroscopy of hydrated cobalt anions doped with carbon dioxide $\mathrm{CoCO}_{2}\left(\mathrm{H}_{2} \mathrm{O}\right)_{n}{ }^{-}, n=1-10$, in the $\mathrm{C}=\mathrm{O}$ stretch region, Chem. - Eur. J., 2020, 26, 1074-1081.

59 N. K. Bersenkowitsch, M. Ončák, J. Heller, C. van der Linde and M. K. Beyer, Photodissociation of sodium iodide clusters doped with small hydrocarbons, Chem. - Eur. J., 2018, 24, 12433-12443.

60 J. Heller, M. Ončák, N. K. Bersenkowitsch, C. van der Linde and M. K. Beyer, Infrared multiple photon dissociation of cesium iodide clusters doped with mono-, di- and triglycine, Eur. J. Mass Spectrom., 2019, 25, 122-132.

61 N. K. Bersenkowitsch, M. Ončák, C. van der Linde, A. Herburger and M. K. Beyer, Photochemistry of glyoxylate embedded in sodium chloride clusters, a laboratory model for tropospheric sea-salt aerosols, Phys. Chem. Chem. Phys., 2018, 20, 8143-8151.

62 A. Herburger, C. van der Linde and M. K. Beyer, Photodissociation spectroscopy of protonated leucine enkephalin, Phys. Chem. Chem. Phys., 2017, 19, 10786-10795.

63 R. C. Dunbar, BIRD (blackbody infrared radiative dissociation): evolution, principles, and applications, Mass Spectrom. Rev., 2004, 23, 127-158.

64 M. J. Frisch, G. W. Trucks, H. B. Schlegel, G. E. Scuseria, M. A. Robb, J. R. Cheeseman, G. Scalmani, V. Barone, G. A. Petersson, H. Nakatsuji, X. Li, M. Caricato, A. V. Marenich, J. Bloino, B. G. Janesko, R. Gomperts, B. Mennucci, H. P. Hratchian, J. V. Ortiz, A. F. Izmaylov, J. L. Sonnenberg, D. Williams-Young, F. Ding, F. Lipparini, F. Egidi, J. Goings, B. Peng, A. Petrone, T. Henderson, D. Ranasinghe, V. G. Zakrzewski, J. Gao, N. Rega, G. Zheng, W. Liang, M. Hada, M. Ehara, K. Toyota, R. Fukuda, J. Hasegawa, M. Ishida, T. Nakajima, Y. Honda, O. Kitao, H. Nakai, T. Vreven, K. Throssell, J. A. Montgomery, Jr., J. E. Peralta, F. Ogliaro, M. J. Bearpark, J. J. Heyd, E. N. Brothers, K. N. Kudin, V. N. Staroverov, T. A. Keith, R. Kobayashi, J. Normand, K. Raghavachari, A. P. Rendell, J. C. Burant, S. S. Iyengar, J. Tomasi, M. Cossi, J. M. Millam, M. Klene, C. Adamo, R. Cammi, J. W. Ochterski, R. L. Martin, K. Morokuma, O. Farkas, J. B. Foresman and D. J. Fox, Gaussian 16, Revision A.03, 2016.

65 D. O. Haan and B. J. de Finlayson-Pitts, Knudsen cell studies of the reaction of gaseous nitric acid with synthetic sea salt at 298 K, J. Phys. Chem. A, 1997, 101, 9993-9999.

66 J. Xie, R. Otto, J. Mikosch, J. Zhang, R. Wester and W. L. Hase, Identification of atomic-level mechanisms for gas-phase $\mathrm{X}^{-}+$ $\mathrm{CH}_{3} \mathrm{Y} \mathrm{S}_{\mathrm{N}} 2$ reactions by combined experiments and simulations, Acc. Chem. Res., 2014, 47, 2960-2969. 